\title{
IDENTIFying OPTIMUM HeRbicide MiXtures to MANAge AND Avoid FENOXAPROP-P-ETHYL RESISTANT Phalaris minor IN WHEAT ${ }^{1}$
}

\author{
Identificação de Misturas Eficazes de Herbicidas para o Controle de Phalaris minor Resistente \\ ao Fenoxaprop-p-Ethyl no Trigo
}

ABBAS, T. $^{2}$, NADEEM, M.A. ${ }^{2}$, TANVEER, A. ${ }^{2}$, and AHMAD, R. ${ }^{2}$

\begin{abstract}
Use of herbicide mixtures has been advocated as most effective strategy for avoidance and management of herbicide resistant weeds. Effect of twelve selected treatments of four herbicides (clodinafop-propargil, metribuzin, pinoxaden and sulfosulfuron) two-way mixtures at different doses was investigated against fenoxaprop-p-ethyl resistant and susceptible populations of $P$. minor grown along the wheat plants. In repeated experiment, herbicides mixtures were applied at 3 to 4 leaf stage of $P$. minor under greenhouse conditions. All the herbicide mixtures were effective to control resistant as well as susceptible $P$. minor. Mixtures having $75 \%$ lethal dose of each mixture component provided best control against P. minor. Mixtures with 50\% lethal dose of each herbicide also provided more than $80 \%$ control of $P$. minor. Surviving $P$. minor plants after exposure to herbicide mixtures showed reduced growth and seed production potential. No mixture combination produced phytotoxic effects on wheat plant up to $75 \%$ of lethal dose of each mixture component. Mixtures including clodinafop-propargil + metribuzin, pinoxaden + sulfosulfuron and pinoxaden + metribuzin at $100 \%$ dose of each mixture component produced minor phytotoxic effects on wheat plants and caused no reduction in terms of ultimate growth and grain yield. However, mixture of sulfosulfuron + clodinafop-propargil at 100\% dose of each component was phytotoxic to wheat and caused significant reduction in term of growth and grain yield. So, farmers can use these mixtures even at $75 \%$ of recommended dose of mixture component to control susceptible and resistant $P$. minor in wheat.
\end{abstract}

Keyswords: Herbicide mixtures, resistance management, resistance avoidance, Triticum aestivum, erva-cabecinha.

RESUMO - O uso de misturas de herbicidas tem sido visto como a estratégia mais eficaz para prevenção e controle de plantas daninhas resistentes a herbicidas. Os efeitos de 12 tratamentos, selecionados entre quatro herbicidas (clodinafop-propargil, metribuzin, pinoxadene e sulfosulfuron) com misturas de duas vias em doses diferentes, foram estudados para as populações de $\boldsymbol{P}$. minor resistentes $e$ suscetiveis ao fenoxaprop-p-ethyl e que cresciam ao longo de plantas de trigo. Em experimentos repetidos, as misturas de herbicidas foram aplicadas em três a quatro estádios de crescimento da folha de $\boldsymbol{P}$. minor em casa de vegetação. Todas as misturas de herbicidas foram eficazes para controlar plantas de $\boldsymbol{P}$. minor resistentes e suscetiveis. As misturas com $75 \%$ de dose letal de cada componente ofereceram melhor controle de $\boldsymbol{P}$. minor. As misturas com $50 \%$ da dose letal de cada herbicida também proporcionaram controle de mais de $80 \%$ de P. minor. As plantas que sobreviveram após serem expostas às misturas de herbicidas apresentaram deficiência de crescimento e de produção de sementes. Nenhuma combinação das misturas gerou efeitos fitotóxicos para o trigo em até $75 \%$ da dose letal de cada componente. As misturas com clodinafop-propargil + metribuzin, pinoxadene + sulfosulfuron e pinoxadene + metribuzin a 100\% da dose de cada componente produziram leves efeitos fitotóxicos em plantas de trigo e não causaram redução em termos de crescimento final e rendimento de grãos. No entanto, a mistura de sulfosulfuron + clodinafop-propargil a 100\% da dose de cada componente foi fitotóxica ao trigo e causou redução significativa do crescimento e produtividade de grãos. Portanto, os agricultores podem utilizar essas misturas, mesmo a $75 \%$ da dose recomendada de componente, para controlar plantas de $\boldsymbol{P}$. minor suscetiveis e resistentes ao trigo.

Palavras-chave: misturas de herbicidas, controle da resistência, impedimento da resistência, Triticum aestivum, littleseed alpista.

Recebido para publicação em 16.3.2016 e aprovado em 2.6.2016.

2 Department of Agronomy, University of Agriculture, Faisalabad, 38040 (Pakistan), <tagondaluaf@gmail.com>. 


\section{INTRODUCTION}

Wheat (Triticum aestivum) is a staple food of Pakistani people and it is considered a key component of global food security. Among the challenges of wheat production sustainability, the issue of herbicide resistant weeds is the most relevant. Phalaris minor (littleseed canary grass) is a major issue and the most challenging weed of wheat crop and found in more than 60 countries around the world (Travlos, 2012). Depending upon the intensity of littleseed canarygrass, emergence time, competition period with wheat, agronomic practices and climatic conditions yield losses in wheat due to this grass may vary from 25 to 50\% (Chhokar and Sharma, 2008) and may result in complete wheat crop failure, due to heavy infestation $\left(2,000-3,000\right.$ plants $\left.\mathrm{m}^{-2}\right)$ (Chhokar et al., 2006). Duary and Yaduraju (2005) have claimed that as the density of littleseed canarygrass increased from 0 to 200 plants $\mathrm{m}^{-2}$, wheat grain yield reduced by $32.6 \%$. Due to its morphological resemblances with wheat crop, $P$. minor control is totally herbicide dependent (Chhokar et al., 2008). Unfortunately, $P$. minor resistance against most of the commonly used herbicides has been increasing in many countries around the world (Heap, 2015). Recently cross resistance problems in $P$. minor have also been reported (Heap, 2015). Therefore, alternative strategies to help avoid the development of resistance and to manage resistant $P$. minor is crucial for the sustainability of wheat.

The use of herbicide mixtures with two or more than two sites of chemistries is an important strategy to manage resistant weeds and to delay the development of herbicide resistance (Lagator, 2013). Based on compounded resistance, frequency models and field experiments, herbicide mixtures have been proved more effective to delay and avoid resistance than herbicide rotation or sequence (Diggle et al., 2003; Beckie, 2006). Quick evolution of resistance occurred due to the selection pressure imposed by exposure to single herbicide with same mode of action. The advantage of using herbicides with more than one mode of action is that resistant biotypes selected by one herbicide were killed by partner herbicide in the mixture
(Diggle et al., 2003). The mixtures are also an effective strategy to control herbicide resistant weeds by exploring the reduced fitness of resistant weeds and due to negative cross resistance (Beckie, 2006). Partner herbicides must have different modes of action to make herbicide mixtures more efficient in delaying and preventing resistance (Friesen et al., 2000; Beckie and Reboud, 2009). Tank mixture of acetolactate synthase (ALS) herbicides with MCPA have proved very effective to manage and delay resistance development in different weed species. Delay in resistance was more prominent in weed species that were selfpollinated in nature (Guia..., 2005; Beckie, 2006).

However, form a growers' standpoint, use of mixtures is normally not preferred as they increase the cost of weed control and may damage crop plants (Hart and Pimentel, 2002). From a researcher perspective, it is a very important and effective strategy to manage the problem of resistance development in weeds to ensure the sustainability of the chemical weed control method, which is cheaper and extensively used as weed control method. Additionally, it has been reported that herbicide synergistic mixtures may be successfully applied at lower individual rate than recommended, to avoid and manage resistance (Little and Tardif, 2005; Caseley et al., 2013). Use of cost effective synergistic mixtures of different herbicides is common under field conditions to manage and avoid resistant weeds in crops (Little and Tardif 2005; Beckie 2006; Caseley et al., 2013). However, no information has been found in the literature on the use of herbicide mixtures to manage $P$. minor in wheat. Therefore, this research aimed to evaluate the efficacy of different herbicide mixtures at range of doses to control fenoxaprop-p-ethyl resistant and susceptible biotypes of $P$. minor. Additionally, the effects of herbicide mixtures on the growth and yield of wheat plants were also investigated.

\section{MATERIALS AND METHODS}

Studies were conducted twice in a greenhouse at the Agronomic Research Area, University of Agriculture, Faisalabad, Pakistan, during 2014-2015. The greenhouse 
was located about $31.25^{\circ} \mathrm{N}$ latitude, $73.09^{\circ} \mathrm{E}$ longitude and altitude of $184 \mathrm{~m}$. The mean minimum and maximum temperatures at the experimental site were $25 \pm 2{ }^{\circ} \mathrm{C}$ and $33 \pm 2{ }^{\circ} \mathrm{C}$, respectively. Herbicides free soil was collected from research fields near the experimental site. Each tray $(45 \times 30 \times 30 \mathrm{~cm})$ was filled with $15 \mathrm{~kg}$ sandy loam soil having $1.10 \%$ organic matter content and $\mathrm{pH}$ of $8.0-$ 8.5. The experiment was laid out in completely randomized design with factorial arrangement having four replications and reshuffled each week in order to achieve uniform growth conditions for all trays. Three rows of wheat variety Glaxy-2013 were sown in each metal tray. $P$. halaris minor seeds were sown between wheat rows. To start, 1.2 liter of water was applied to each tray and then trays were kept moist throughoutout the experimental period.

The herbicides used in this study were: Clodinafop -propargyl [Acetyl-CoA carboxylase (ACCase) inhibitor], metribuzin (Photosystem II inhibitor), pinoxaden (ACCase inhibitor),

Table 1 - Herbicide mixtures at range of doses for Phalaris Minor

\begin{tabular}{|c|c|}
\hline Treatment & Herbicides mixture \\
\hline CM1 & $\begin{array}{l}\text { Clodinafop-propargil } 50 \% \text { of } \mathrm{R}+\text { metribuzin } 50 \% \\
\text { of } \mathrm{R}\end{array}$ \\
\hline CM1.5 & $\begin{array}{l}\text { Clodinafop-propargil } 75 \% \text { of } \mathrm{R}+\text { metribuzin } 75 \% \\
\text { of } \mathrm{R}\end{array}$ \\
\hline $\mathrm{CM} 2$ & $\begin{array}{l}\text { Clodinafop-propargil } 100 \% \text { of } \mathrm{R}+\text { metribuzin } \\
100 \% \text { of } \mathrm{R}\end{array}$ \\
\hline PS1 & Pinoxaden $50 \%$ of $\mathrm{R}+$ sulfosulfuron $50 \%$ of $\mathrm{R}$ \\
\hline PS1.5 & Pinoxaden $75 \%$ of $\mathrm{R}+$ sulfosulfuron $75 \%$ of $\mathrm{R}$ \\
\hline PS2 & Pinoxaden $100 \%$ of $\mathrm{R}+$ sulfosulfuron $100 \%$ of $\mathrm{R}$ \\
\hline PM1 & Pinoxaden $50 \%$ of $\mathrm{R}+$ metribuzin $50 \%$ of $\mathrm{R}$ \\
\hline PM1.5 & Pinoxaden $75 \%$ of $\mathrm{R}+$ metribuzin $75 \%$ of $\mathrm{R}$ \\
\hline PM2 & Pinoxaden $100 \%+$ metribuzin $100 \%$ of R \\
\hline $\mathrm{SC} 1$ & $\begin{array}{l}\text { Sulfosulfuron } 50 \% \text { of } \mathrm{R}+\text { clodinafop-propargil } \\
50 \% \text { of } \mathrm{R}\end{array}$ \\
\hline $\mathrm{SC} 1.5$ & $\begin{array}{l}\text { Sulfosulfuron } 75 \% \text { of } R+\text { clodinafop-propargil } \\
75 \% \text { of } R\end{array}$ \\
\hline $\mathrm{SC} 2$ & $\begin{array}{l}\text { Sulfosulfuron } 100 \% \text { of } R+\text { clodinafop-propargil } \\
100 \% \text { of R }\end{array}$ \\
\hline WC & Weedy check \\
\hline $\mathrm{C}$ & Manual weed control \\
\hline
\end{tabular}

$\mathrm{R}$ represents the recommended doses of herbicides e.i. Clodinafoppropargil (C), metribuzin (M), Pinoxaden (P) and Sulfosulfuron (S). CM Treatments, for example, refer to the mixture of clodinafop-propargil and metribuzin at 50\% (CM1), 75\% (CM1.5) and $100 \%(\mathrm{CM} 2)$ of $\mathrm{R}$ of each mixture herbicide, respectively. sulfosulfuron (ALS inhibitor). The herbicides were used in different combination (Table 1). The herbicide mixtures were sprayed using a $\mathrm{CO}_{2}$ pressurized backpack sprayer fitted with TeeJet $8003 \mathrm{VS}$ nozzle at 30 psi pressure that sprayed about 20 gallons of water per acre. Sprayer calibration was done and amount of spray solution were calculated for one square matter. All replications trays of same treatment were placed in one square matter and spray was carried out. Data regarding weed mortality, plants height and dry biomass for both $P$. minor and wheat were recorded at three weeks after herbicide application and at maturity. The dry biomass, spike length, number of grains per spike, 100 grain weight and grain yield per plant for wheat and number of seeds per spike of $P$. minor were also recorded at maturity.

Our objective was to compare the efficacy of different mixtures at range of doses to control $P$. minor in wheat. Therefore to analyze data and comparison of all treatments, Fisher's analysis of variance techniques was carried out using Tukey's honest test at 5\% probability level (Steel et al., 1997). Pooled data were used for analysis because repeated experiment gave statistically similar results.

\section{RESULTS AND DISCUSSION}

Our results showed that herbicide mixtures can be successfully used to control fenoxaprop-p-ethyl resistant and susceptible $P$. minor. There was no difference in the response of fenoxaprop-p-ethyl resistant and susceptible population of $P$. minor to the tested herbicides mixtures. Same efficacy of mixtures against resistant and susceptible populations of $P$. minor was due to no cross resistance in $P$. minor populations against selected mixtures. During this study fenoxaprop-p-ethyl was not used as a mixture component in any of the mixtures. Effective control of resistant weed populations with herbicide mixtures has been reported in previous findings (Beckie and Reboud, 2009).

Results on the response of fenoxaprop-pethyl resistant population and wheat plants to the herbicide mixtures application have been described. 


\section{Effect of herbicides mixtures on $P$. minor, data were collected three weeks after mixtures application}

Results showed that herbicides mixtures combinations (CM1.5, CM2, PS1.5, PS2, PM1.5, $\mathrm{PM} 2, \mathrm{SC} 1.5, \mathrm{SC} 2$ and C) containing 75 and $100 \%$ doses of each mixture herbicide caused $100 \%$ mortality of $P$. minor. Mixtures at low doses including CM1, PS1, PM 1 and SC1 caused $85.00,84.33,81.00$ and 81.67 percent mortality respectively (Table 2 ). However, plant height and dry biomass of surviving plants were significantly reduced due to mixtures application as compared to control plants (Table 2).

\section{Effect of herbicides mixtures on $P$. minor, data were collected at maturity}

Results about plant height at maturity revealed that toxicity caused by mixtures application sustained up to plant maturity and significantly reduced the plant height $(46.53$, $48.14,42.80$ and $37.41 \mathrm{~cm}$ ) as compared to control $(70.30 \mathrm{~cm})$ (Table 3). Dry biomass of mixture exposed plants was also significantly lower than plants not treated with any mixture (C). Minimum dry biomass as compared to other mixtures treatments was produced in $\mathrm{SC} 1$ (1.95 g) and maximum biomass was produced by control plant (C) (Table 3). Seed production potential of mixtures exposed plants was also considerably reduced as compared to control. Plants exposed to CM1, PS1, PM1 and SC1 produced 53.32, 67.41, 58.37 and 43.17 seeds per plant respectively. However, Phalaris minor plants of control pots (C) produced 178.03 seeds per plant (Table 3). Mixtures were effective when components were used at or lower than $75 \%$ to their recommended dose. When mixtures were used at $50 \%$ of each herbicide recommended dose, decrease in control efficacy was observed. Our results support previous findings, which suggested the use of mixtures components at close to or at their recommended doses for efficient weed control (Russell, 2005; Beckie, 2006; Lagator, 2013). It was also observed that plants that survived after being exposed to low doses of herbicides mixtures had significantly reduced growth and lesser seeds than control. Reduced growth and low seed production of $P$. minor plant treated with herbicide above the doses caused hormesis is supported by Abbas et al. (2016).

Herbicides mixtures of two or more than two different herbicides are recommended to slow down the development of resistance and to control resistant weeds, due to their reduced fitness and negative cross resistance (Beckie, 2006). However, herbicides in the mixtures

Table 2 - Efficacy of herbicide mixtures to control P. minor, data were collected two weeks after spray

\begin{tabular}{|c|c|c|c|}
\hline Herbicide mixture & Mortality (\%) & Plants height $(\mathrm{cm})$ & Biomass (g per plant) \\
\hline CM1 & $85.00 \pm 4.47 \mathrm{~b}$ & $9.67 \pm 0.44 \mathrm{bc}$ & $1.80 \pm 0.08 \mathrm{~b}$ \\
\hline CM1.5 & $100.00 \pm 0.00 \mathrm{a}$ & -- & -- \\
\hline CM2 & $100.00 \pm 0.00 \mathrm{a}$ & -- & $2.00 \pm 0.11 \mathrm{~b}$ \\
\hline PS1 & $84.33 \pm 5.39 \mathrm{~b}$ & $10.57 \pm 0.60 \mathrm{~b}$ & -- \\
\hline PS1.5 & $100.00 \pm 0.00 \mathrm{a}$ & -- & -- \\
\hline PS2 & $100.00 \pm 0.00 \mathrm{a}$ & -- & $1.87 \pm 0.06 \mathrm{~b}$ \\
\hline PM1 & $81.00 \pm 3.22 \mathrm{~b}$ & $7.76 \pm 0.31 \mathrm{c}$ & -- \\
\hline PM1.5 & $100.00 \pm 0.00 \mathrm{a}$ & -- & -- \\
\hline PM2 & $100.00 \pm 0.00 \mathrm{a}$ & -- & $1.95 \pm 0.11 \mathrm{~b}$ \\
\hline SC1 & $81.67 \pm 2.58 \mathrm{~b}$ & $8.13 \pm 0.50 \mathrm{c}$ & -- \\
\hline SC1.5 & $100.00 \pm 0.00 \mathrm{a}$ & -- & -- \\
\hline SC2 & $100.00 \pm 0.00 \mathrm{a}$ & -- & $2.37 \pm 0.12 \mathrm{a}$ \\
\hline WC & $0.00 \pm 0.00 \mathrm{c}$ & -- \\
\hline C & $100.00 \pm 0.00 \mathrm{a}$ & -- & \\
\hline
\end{tabular}

The means marked with same letter do not differ significantly at $5 \%$ confidence level. Data are the means \pm standard error. 
Table 3 - Efficacy of herbicide mixtures to control P. minor, data were collected at maturity

\begin{tabular}{|c|c|c|c|}
\hline Herbicide mixture & Plants height $(\mathrm{cm})$ & Biomass (g per plant) & No. of seeds per plant \\
\hline CM1 & $46.53 \pm 2.20 \mathrm{~b}$ & $2.40 \pm 0.10 \mathrm{~b}$ & $53.32 \pm 2.53 \mathrm{bc}$ \\
\hline CM1.5 & -- & -- & -- \\
\hline CM2 & -- & -- & -- \\
\hline PS1 & $48.14 \pm 2.81 \mathrm{~b}$ & $2.49 \pm 0.13 \mathrm{~b}$ & -- \\
\hline PS1.5 & -- & -- & -- \\
\hline PS2 & -- & -- & $58.37 \pm 2.46 \mathrm{bc}$ \\
\hline PM1 & $42.80 \pm 1.79 \mathrm{bc}$ & $2.62 \pm 0.09 \mathrm{~b}$ & -- \\
\hline PM1.5 & -- & -- & -- \\
\hline PM2 & -- & -- & $43.17 \pm 2.77 \mathrm{c}$ \\
\hline SC1 & $37.41 \pm 2.39 \mathrm{c}$ & $1.95 \pm 0.11 \mathrm{c}$ & - \\
\hline SC1.5 & -- & -- & -- \\
\hline SC2 & -- & -- & $178.03 \pm 9.64 \mathrm{a}$ \\
\hline WC & $70.30 \pm 4.12 \mathrm{a}$ & $3.49 \pm 0.18 \mathrm{a}$ & -- \\
\hline C & -- & -- & \\
\hline
\end{tabular}

The means marked with same letter do not differ significantly at $5 \%$ confidence level. Data are the means \pm standard error.

should have different mode of action and have same weed control efficacy to avoid resistance evolution (Friesen et al., 2000; Guia..., 2005; Beckie, 2006) as used in this present study. Different herbicides mixtures have been successfully used to control different types of weeds without development of resistance even after twenty years (Wrubel and Gressel, 1994). However, mixtures are not preferred because it may increase the cost of weed control and also result in crop damage. In present studies mixtures synergistically control $P$. minor even at lower doses of mixtures components $(50 \%$ or $75 \%$ of $\mathrm{R}$ for each herbicide). At $75 \%$ doses of each mixture herbicides $100 \%$ weed control efficacy was achieved (Table 2). Use of mixtures at lower doses will reduce the cost of weed control. Literature exposed that herbicides mixtures may be applied at lower individual rate of each mixture component in mixture than recommended to avoid resistance (Little and Tardif, 2005; Beckie, 2006; Caseley et al., 2013).

Effect of mixtures application on wheat growth, data were collected three weeks after mixtures application and at maturity

Results of data collected two weeks after mixtures application showed that herbicides mixtures inhibited growth of wheat plants at higher doses $(100 \%$ or $\mathrm{R}$ of each herbicide in mixture) e.i. CM2, PS2, PM2 and SC2. However, at $50 \%$ and $75 \%$ of $\mathrm{R}$ in mixture did not cause significant reduction in plant height and dry biomass of wheat (Table 4). Results of data collected at maturity showed that inhibitory response of herbicide mixtures did not remain with time. Herbicides mixtures did not caused reduction in plant height at maturity except PM1 and SC1. Dry biomass of wheat also showed no significant effect of any mixture application at any doses (Table 4).

\section{Effect of mixtures application on grain yield and yield contributing parameters of wheat}

The effect of mixtures application on wheat yield was investigated by collecting data on grain weight and yield contributing parameters of wheat including spike length, number of grains per spike and 100 grain weight. Results on spike length showed no significant inhibitory effect of any mixture application on spike length (Table 5). Herbicide mixtures caused no significant reduction on number grain produced per spike except SC2 and $\mathrm{WC}$ which caused reduction in number of grain produced per spike (Table 5). Results of 100 grain weight revealed that mixtures applications did not affect grain weight expect SC1.5 and SC2 (Table 5). Minimum 100 grain 
Table 4 - Effect of herbicide mixtures on wheat growth, data were collected three weeks after spray and at maturity

\begin{tabular}{|c|c|c|c|c|}
\hline \multirow{2}{*}{ Herbicide mixture } & \multicolumn{2}{|c|}{ Three weeks after spray } & \multicolumn{2}{c|}{ At maturity } \\
\cline { 2 - 5 } & Plants height $(\mathrm{cm})$ & Biomass (g per plant) & Plant height (cm) & Biomass (g per plant) \\
\hline CM1 & $29.07 \pm 1.37 \mathrm{a}$ & $2.52 \pm 0.11 \mathrm{abc}$ & $60.11 \pm 2.53 \mathrm{a}$ & $3.64 \pm 0.15^{\mathrm{NS}}$ \\
\hline CM1.5 & $29.27 \pm 1.06 \mathrm{a}$ & $2.52 \pm 0.08 \mathrm{abc}$ & $61.51 \pm 2.04 \mathrm{a}$ & $3.68 \pm 0.12$ \\
\hline CM2 & $23.89 \pm 1.66 \mathrm{bc}$ & $2.23 \pm 0.14 \mathrm{bcd}$ & $58.31 \pm 3.64 \mathrm{a}$ & $3.57 \pm 0.23$ \\
\hline PS1 & $29.16 \pm 1.70 \mathrm{a}$ & $2.45 \pm 0.13 \mathrm{abcd}$ & $62.58 \pm 3.26 \mathrm{a}$ & $3.51 \pm 0.19$ \\
\hline PS1.5 & $30.74 \pm 1.12 \mathrm{a}$ & $2.55 \pm 0.08 \mathrm{abc}$ & $62.48 \pm 2.06 \mathrm{a}$ & $3.64 \pm 0.12$ \\
\hline PS2 & $23.41 \pm 1.62 \mathrm{bc}$ & $2.19 \pm 0.14 \mathrm{~cd}$ & $57.36 \pm 3.58 \mathrm{a}$ & $3.37 \pm 0.21$ \\
\hline PM1 & $30.15 \pm 1.26 \mathrm{a}$ & $2.63 \pm 0.10 \mathrm{a}$ & $58.37 \pm 2.20 \mathrm{a}$ & $3.59 \pm 0.13$ \\
\hline PM1.5 & $27.32 \pm 0.99 \mathrm{ab}$ & $2.61 \pm 0.08 \mathrm{ab}$ & $58.58 \pm 1.96 \mathrm{a}$ & $3.62 \pm 0.11$ \\
\hline PM2 & $22.28 \pm 1.05 \mathrm{c}$ & $2.39 \pm 0.10 \mathrm{abcd}$ & $39.74 \pm 1.78 \mathrm{~b}$ & $3.53 \pm 0.15$ \\
\hline SC1 & $27.81 \pm 1.78 \mathrm{ab}$ & $2.49 \pm 0.15 \mathrm{abcd}$ & $61.18 \pm 3.83 \mathrm{a}$ & $3.49 \pm 0.22$ \\
\hline SC1.5 & $28.87 \pm 1.68 \mathrm{a}$ & $2.45 \pm 0.13 \mathrm{abcd}$ & $59.69 \pm 3.10 \mathrm{a}$ & $3.43 \pm 0.18$ \\
\hline SC2 & $20.20 \pm 1.17 \mathrm{c}$ & $2.12 \pm 0.11 \mathrm{~d}$ & $45.24 \pm 2.36 \mathrm{~b}$ & $3.30 \pm 0.17$ \\
\hline WC & $28.87 \pm 1.68 \mathrm{a}$ & $2.40 \pm 0.13 \mathrm{abcd}$ & $56.80 \pm 2.95 \mathrm{a}$ & $3.39 \pm 0.18$ \\
\hline C & $29.94 \pm 1.58 \mathrm{a}$ & $2.56 \pm 0.12 \mathrm{abc}$ & $64.73 \pm 3.04 \mathrm{a}$ & $3.65 \pm 0.17$ \\
\hline
\end{tabular}

The means marked with same letter do not differ significantly at $5 \%$ confidence level. Data are the means \pm standard error. NS $=$ nonsignificant $(\mathrm{p} \leq 0.05)$

Table 5 - Effect of herbicide mixtures on wheat grain yield and yield contributing parameters, data were collected at maturity

\begin{tabular}{|l|c|c|c|c|}
\hline $\begin{array}{c}\text { Herbicide } \\
\text { mixture }\end{array}$ & Spike length $(\mathrm{cm})$ & No. of grain per spike & 100 grain weight $(\mathrm{g})$ & Grain yield (g per plant) \\
\hline CM1 & $8.70 \pm 0.39^{\mathrm{NS}}$ & $44.59 \pm 2.11 \mathrm{a}$ & $3.47 \pm 0.15 \mathrm{a}$ & $1.39 \pm 0.06 \mathrm{ab}$ \\
\hline CM1.5 & $8.63 \pm 0.30$ & $43.92 \pm 1.60 \mathrm{ab}$ & $3.39 \pm 0.11 \mathrm{a}$ & $1.36 \pm 0.05 \mathrm{ab}$ \\
\hline CM2 & $8.48 \pm 0.57$ & $43.02 \pm 2.99 \mathrm{ab}$ & $3.31 \pm 0.21 \mathrm{ab}$ & $1.31 \pm 0.08 \mathrm{ab}$ \\
\hline PS1 & $8.55 \pm 0.48$ & $43.32 \pm 2.53 \mathrm{ab}$ & $3.30 \pm 0.17 \mathrm{ab}$ & $1.51 \pm 0.07 \mathrm{ab}$ \\
\hline PS1.5 & $8.76 \pm 0.30$ & $41.97 \pm 1.53 \mathrm{ab}$ & $3.42 \pm 0.11 \mathrm{a}$ & $1.46 \pm 0.53 \mathrm{ab}$ \\
\hline PS2 & $8.53 \pm 0.58$ & $39.20 \pm 2.73 \mathrm{abc}$ & $3.37 \pm 0.21 \mathrm{a}$ & $1.46 \pm 0.09 \mathrm{ab}$ \\
\hline PM1 & $8.33 \pm 0.33$ & $43.77 \pm 1.83 \mathrm{ab}$ & $3.26 \pm 0.12 \mathrm{ab}$ & $1.48 \pm 0.05 \mathrm{ab}$ \\
\hline PM1.5 & $8.74 \pm 0.30$ & $45.88 \pm 1.67 \mathrm{a}$ & $3.34 \pm 0.10 \mathrm{ab}$ & $1.53 \pm 0.05 \mathrm{a}$ \\
\hline PM2 & $8.59 \pm 0.39$ & $42.65 \pm 2.02 \mathrm{ab}$ & $3.27 \pm 0.14 \mathrm{ab}$ & $1.37 \pm 0.06 \mathrm{ab}$ \\
\hline SC1 & $8.50 \pm 0.52$ & $39.33 \pm 2.51 \mathrm{abc}$ & $3.28 \pm 0.19 \mathrm{ab}$ & $1.44 \pm 0.08 \mathrm{ab}$ \\
\hline SC1.5 & $8.57 \pm 0.48$ & $38.51 \pm 2.25 \mathrm{abc}$ & $3.28 \pm 0.17 \mathrm{ab}$ & $1.30 \pm 0.06 \mathrm{~b}$ \\
\hline SC2 & $8.58 \pm 0.49$ & $33.69 \pm 1.96 \mathrm{c}$ & $2.70 \pm 0.14 \mathrm{c}$ & $0.86 \pm 0.05 \mathrm{c}$ \\
\hline WC & $8.56 \pm 0.48$ & $36.58 \pm 2.13 \mathrm{bc}$ & $2.80 \pm 0.14 \mathrm{bc}$ & $0.93 \pm 0.05 \mathrm{c}$ \\
\hline C & $8.65 \pm 0.44$ & $45.41 \pm 2.40 \mathrm{a}$ & $3.41 \pm 0.16 \mathrm{a}$ & $1.45 \pm 0.06 \mathrm{ab}$ \\
\hline
\end{tabular}

The means marked with same letter do not differ significantly at the $5 \%$ confidence level. Data are the means \pm standard error. NS $=$ nonsignificant $(\mathrm{p} \leq 0.05)$.

weight $(2.70 \mathrm{~g})$ was obtained in plants that were treated with SC2 which was followed by WC $(2.80 \mathrm{~g})$. Mixtures application effect on grain yield per plant was also not significant for CM2, PS2 and PM2 mixtures at their varied doses (Table 5). However, SC2 caused significant reduction in grain yield per plant $(0.86 \mathrm{~g})$, which was followed by WC (0.93).
The phytotoxic effect of herbicide mixtures on crop plants is one of the major constraints to the use of herbicides mixtures in crop production. Our results showed that three types of herbicides mixtures including Clodinafop-propargil + metribuzin, Pinoxaden + sulfosulfuron and Pinoxaden + metribuzin can be effectively used to control $P$. minor 
without phytotoxic effect on wheat plants (Tables 4 and 5). However, mixture of Sulfosulfuron and clodinafop-propargil caused phytotoxic effect at higher doses $(100 \%$ of $\mathrm{R}$ for each mixture component). Our findings reinforce previous research on the control of weeds in rice field using herbicide mixtures at varied doses with no phytotoxic effect on crop plants (Beckie, 2006). Inhibited growth and biomass reduction due to exposure of herbicide mixtures was recovered by wheat plant and no significant effect was observed at maturity (Table 5). Recovery to phytotoxic effects of herbicides has been reported for wheat plant by Hosseini et al. (2011) and Bhullar et al. (2012).

Finally, herbicide mixtures e.i. clodinafoppropargil + metribuzin, pinoxaden + sulfosulfuron and pinoxaden + metribuzin can be effectively used at range of doses to avoid and control resistant $P$. minor in wheat crop with no phytotoxic effects on wheat. Sulfosulfuron + clodinafop-propargyil was phytotoxic to wheat and caused reduction in grain yield. However, the use of multiple herbicides in agriculture must be considered in the light of economic and environmental concerns of herbicide mixtures.

\section{REFERENCES}

Abbas T. et al. Low doses of fenoxaprop-p-ethyl cause hormesis in littleseed canarygrass (Phalaris minor Retz.) and wild oat (Avena fatua L.). Planta Daninha. 2016;34:527-33.

Guide to crop protection: weeds, plant diseases, insects. Biprovincial publication. Regina, SK: Saskatchewan Agriculture, Food and Rural Revitalization; Winnipeg, MB: Manitoba Agriculture, Food and Rural Initiatives, 2005. 354p.

Beckie H.J. Herbicide-resistant weeds: management tactics and practices. Weed Technol. 2006;20:793-814.

Beckie H.J., Reboud X. Selecting for weed resistance: herbicide rotation and mixture. Weed Technol. 2009;23:36370 .

Bhullar M.S. et al. Bioefficacy of herbicides in relation to sowing methods in wheat. Indian J Weed Sci. 2012;44:2147.

Caseley J.C. et al. Herbicide resistance in weeds and crops. new York: Elsevier, 2013.15p.
Chhokar R.S. et al. Herbicides for control of isoproturonresistant Littleseed Canarygrass (Phalaris minor) in wheat. Crop Protec. 2008;27:719-26.

Chhokar R.S. et al. Evaluation of herbicides against Phalaris minor in wheat in north western Indian lains. Weed Res. 2006;46:40-9.

Diggle A. et al. Herbicides used in combination can reduce the probability of herbicide resistance in finite weed populations. Weed Res. 2003;43:371-82.

Duary B., Yaduraju N.T. Estimation of yield losses of wheat (Triticum aestivum L.) caused by littleseed canarygrass (Phalaris minor Retz.) competition. J Crop Weed. 2005;2:812.

Friesen L.S. et al. Management strategies for attenuating herbicide resistance: untoward consequences of their promotion. Crop Protec. 2000;19:891-5.

Hart K., Pimentel D. Environmental and economic costs of pesticide use. In: Pimentel D., editor. Encyclopedia of pest management. Boca Raton: CRC Press, 2002. 3v. p.237-9.

Heap I. The international survey of herbicide resistant weeds [Internet]. Thursday, October 29, 2015. Available at: www.weedscience.org

Hosseini S.A. et al. Response of wild barley (Hordeum spontaneum) and winter wheat (Triticum aestivum) to sulfosulfuron: the role of degradation. Weed Biol Manage. 2011;11:64-71.

Lagator M. et al. Herbicide mixtures at high doses slow the evolution of resistance in experimentally evolving populations of Chlamydomonas reinhardtii. New Phytol. 2013;198:93845.

Little R., Tardif E.J. Combinations of herbicides at reduced rates for the prevention of herbicide resistance. Weed Sci Soc Am. 2005;45:111.

Russell P.E. A century of fungicide evolution. J Agric Sci. 2005;143:11-25.

Steel R.G.D. et al. Principles and procedures of statistics. A biometrical approach. $3^{\text {rd }}$.ed. New York: McGraw-Hill, 1997. p.172-7.

Travlos I. Evaluation of herbicide-resistance status on populations of littleseed canarygrass (Phalaris minor Retz.) from southern Greece and suggestions for their effective control. J Plant Protec Res. 2012;52:308-13.

Wrubel R.P., Gressel J. Are herbicide mixtures useful for delaying the rapid evolution of resistance? A case study. Weed Technol. 1994;8:635-48. 